R. O. Dychkovskyi ${ }^{1}$, Dr. Sc. (Tech.), Prof., orcid.org/0000-0002-3143-8940, V.H. Lozynskyi ${ }^{1}$, Cand. Sc. (Tech.), orcid.org/0000-0002-9657-0635, P. B. Saik ${ }^{1}$, Cand. Sc. (Tech.), orcid.org/0000-0001-7758-1083, Yu. V. Dubiei ${ }^{1}$, Cand. Sc. (Econ.), orcid.org/0000-0003-3415-3470, E. Cáceres Cabana ${ }^{2}$, Cand. Sc. (Tech.), Assoc. Prof., orcid.org/0000-0002-0066-1349, Ia. T. Shavarskyi ${ }^{3}$

\title{
TECHNOLOGICAL, LITHOLOGICAL AND ECONOMIC ASPECTS OF DATA GEOMETRIZATION IN COAL MINING
}

Purpose. Creation of a favorable geomechanical situation and estimation of economical parameters at the mining area according to the selection of the relevant technical and technological justification and operating modes of the mechanized fastening based on the planning of zones of variable stresses.

Methodology. Methods of mathematical modeling for determination of loads for fastening of mechanized complexes, experimental studies on stressed-deformed state of the rock mass are applied, on the basis of which rational parameters of mining and management mining pressure are formed.

Findings. Using the developed method of data geometrization, the lithological and geological structure of the rock mass was restored on the intersections of the surrounding wallface two of preparatory workings. On this basis, a change in the stress-strain state of a rock massif is established. This makes it possible to set the loadings on the fastening of mechanized complexes. This approach establishes the mathematical dependencies that determine the zones of elevated and lowered mining pressure. For the measure of transition, the so-called coefficient of lithological difference is defined. This parameter provides the possibility not only to evaluate the geomechanical situation at the extraction site, but also to establish a marginal zone for the development of reserves with traditional and radical technologies. An economic evaluation of the proposed technical and technological measures has been held separately. The results of the research will allow justifying the effective mining of coal reserves in particular geological conditions.

Originality. The dependence of the lithological difference formation of rocks and stresses of the rockmass to create conditions for the development of the coal reserves has been established. An economic evaluation of the decisions was made using the wellknown methodology of UNIDO.

Practical value. Obtained results of experimental studies with precision sufficient for practical application can be used to determine the parameters of underground mining and provide an opportunity to extract the coal reserves at an economically suitable level. The proposed technological solutions were checked in practical conditions for the development of the coal reserves at the site of a DTEK company mine.

Keywords: data geometrization, lithological structure, coal reserves, traditional and radical technologies, economic evaluation

Introduction. Coal is the main fossil fuel used in power generation. Coal makes about $70 \%$ of world reserves of energy resources [1]. In the context of the current production capacities, Ukrainian coal-mining industry can operate effectively for at least 200 years. Unfortunately, $65.9 \%$ of all prospected reserves are concentrated in seams whose thickness is less than $1.2 \mathrm{~m} \mathrm{[2].} \mathrm{The} \mathrm{fact} \mathrm{that} \mathrm{their} \mathrm{majority} \mathrm{is} \mathrm{deposited} \mathrm{in}$ slightly sloping seams is the feature of spatial location of the deposits.

Moreover, reserves of mineral deposits experience their constant increase which can be explained by gradual depletion of more standard-quality and practical non-availability of new operation enterprises [3].

World practices confirm the inexpediency of traditional complex and machine mining of such reserves due to high cost of coal extraction and insufficient safety of miners in the process of underground operations [4]. For nearly a decade, dynamics of fuel and energy balance in the world will experience significant changes. Coal as a component of energy feedstock will play more important role [5]. That involves the improvement of methods and technologies concerning the development of thin and very thin seams. The increasing complexity of extracting and drifting operations will factor into the changes in facilities for all technological processes in mining [6].

(C) Dychkovskyi R. O., Lozynskyi V.H., Saik P. B., Dubiei Yu.V., Cáceres Cabana E., Shavarskyi Ia. T., 2019
It is indubitable today that a fossil fuel share in fuel and energy complex will grow constantly [7]. History of formation and development of the coal industry in Ukraine has shown that coal was, is, and will be a guarantor of sustainable development of the country's economy [8].

The fact is included in the standards of the national economy development. Energy program of Ukraine for the period until 2010 (Resolution of Verkhovna Rada of Ukraine of 15 June 1996 \#191/196-130) stipulates $50 \%$ coal share increase in fuel and energy balance of Ukraine. Production activities of coal-mining industry are accompanied by the involvement of thin seams, and seam with complicated mining and geological, hydrogeological, and geotechnical conditions. Mining operations wave deepen which results in the rise of rock pressure, gas emission and other negative dynamic phenomena. That stipulates the necessity to apply comprehensive approach while consolidating scientific potential and coordinating all technological processes connected with coal extraction from thin coal seams and very thin ones.

Literature review. In the technical literature, the methods for determining the geometrization of the objects are highlighted fairly low. The formation of such systems for mining conditions is practically absent and, mainly, they are related to the issue of maps mining surveying. Therefore, the authors make some corrections for the construction of the mathematical model, concerning, in the first place, the setting of the coordinate system of reproducible geometric bodies. 
A well-known method of geometrization of deposits is to reproduce planes of contacts, primarily of minerals, with the help of isoclines of spatial arrangement. The development of modern visualization methods makes it possible to significantly expand the ways of representing and shaping all the components of the lithological structure of the studied areas. The simulation system should objectively reflect the level of mining - geometric study of the formation [9]. They also have the opportunity to adjust the overall picture of the mining in case of obtaining additional data from the exploration wells of the mine or in case of meeting by the extractive work the new abnormal formations.

Unsolved aspects of the problem. The possibility of presenting the rock mass during the underground coal seams mining with the changeable geological and lithological structures, determining the technological aspects of excavation by traditional and non-traditional methods, also as the economical definition of the proposed solutions currently is poorly understood [10].

Research requires introducing highly productive mechanized complexes, as well as presenting the technologies of underground coal gasification. The latest achievements of science and technology are introduced with the purpose of studying new methods for the coal seams extraction in different geological conditions.

Purpose. Objectives of the article are to present the method of data geometrization for simulating the rock mass and geomechanical situation for choosing a proper excavation technique and technology at a profitable economic level.

Basic principles of data geometrization. The basic principles of data geometrization include simulation of a certain simulated system. In this case, the geometric dimensions and physical properties in the system of "natural object-model" are clearly provided. Sufficiently complete basic principles of such investigations are presented in [11]. According to preliminary studies, lithological difference of coal-bearing formation with related physical and chemical properties was simulated with the help of mathematical dependences in the form of corresponding-order polynomial curves

$y_{1}=k_{i} L^{i-1}+k_{i-1} L^{i-2}+\ldots+k_{2} L+k_{1}$;

$y_{2}=k_{2 i} L^{2(i-1)}+k_{2(i-1)} L^{2(i-2)}+\ldots+k_{2.2} L+k^{2.1}$;

$y_{n-1}=k_{(n-1) i} L^{(n-1) i-1}+k_{(n-1)(i-1)} L^{(n-1) i-2}+\ldots+k_{(n-1) 2} L+k_{(n-1) 1} ;$

$y_{n}=k_{n i} L^{n(i-1)}+k_{n(i-1)} L^{n(i-2)}+\ldots+k_{n 2} L+k_{n 1}$,

where $k_{1}-k_{i}$ are empiric coefficients of mining and geological structure of coal-bearing formation according to a site entry; $i$ is quantitative index of polynomial series; $n i$ is the number of stiffness layers of coal-bearing formation; and $L$ is the length of extraction pillar (i. e. abscises in terms of Cartesian coordinates).

Thus, it was also defined that the load applied to the $i^{\text {th }}$ area of extraction pillar is

$$
Q_{i}=\frac{2 \cdot h_{i} \cdot \gamma_{i} \cdot l_{i} \cdot \operatorname{tg} \psi_{i} \cdot l_{l} \cdot \beta_{i}}{S_{k p} \cdot n_{k p}} .
$$

Component parameters of the dependence can be determined by the following expressions

$$
\begin{gathered}
h_{i}=\frac{h_{n}+h_{o}+h_{c}}{k_{n}} ; \gamma_{i}=\frac{\gamma_{n}+\gamma_{o}+\gamma_{c}}{k_{n}} ; \\
l_{i}=\frac{l_{n}+2 l_{o}}{k_{n}} ; \operatorname{tg} \psi_{i}=\frac{\operatorname{tg} \psi_{\tilde{n}}+\operatorname{tg} \psi_{o}+\operatorname{tg} \psi}{k_{n}}
\end{gathered}
$$

where $k_{n}$ is the total number of lithological difference layers being analyzed ( 3 in our situation). follows

$$
\beta_{i}=\beta \cdot K_{1} \cdot K_{2},
$$

where it is expedient to determine $\beta$ as being rock mass stiffness coefficient for mining operations with the help of a mathematical mechanism proposed by professor Savostianov.

Therefore, the lithological structure coefficient involves geometry-physical and mechanical parameters; they determine load applied to the support units $\left(l_{i}, l_{l}, \psi_{i}, \beta_{i}, h_{i}, \gamma_{i}\right)$ per corresponding reduced values $\left(l_{k p r}, l_{l}, \psi_{p r}, \beta_{p r}, h_{p r}, \gamma_{p r}\right)$ according to which energy parameters of the powered systems used to mine minerals under certain mining and geological conditions are selected. Thus, we obtain the dependence

$$
n=\frac{h_{i} \cdot \gamma_{i} \cdot l_{i} \cdot \operatorname{tg} \psi_{i} \cdot \beta_{i}}{h_{k p r} \cdot \gamma_{p r} \cdot l_{p r} \cdot \operatorname{tg} \psi_{p r} \cdot \beta_{p r}} .
$$

To identify the coefficient as that to be used as a tool to correct energy parameters of the powered system along extraction pillars, mine experiments were carried out. So this coefficient is a valid parameter for correcting the fastening of the mechanized complexes also as changing the traditional excavating methods to unconventional ones.

At previous research studies much attention was paid to the application of underground coal gasification technology in faulting zones [12] as well as heat and mass balance study [13]. The application of this technology in different mining and geological conditions is substantiated, ecological and economic aspects of this technology are established [14].

Practical experience of data geometrization. Such studies were provided for Pavlohrad group of mines of DTEK company. We have proved the possibility of using the proposed mathematical mechanism to determine deformation characteristics of rock mass in other mining regions [15]. As an example, we consider the results of studies carried out in terms of one longwall in DTEK company.

The extraction pillar is contoured by site entries: boundary entry (belt or ventilation entry) and belt entry. Coal seam $c_{1}$ is mined by means of a stope (coal grade is DGk - Ukrainian norms). The seam is of simple structure, relatively continuous in its thickness; geological thickness is $0.76-0.97 \mathrm{~m}$. Seam dip is $0-3^{\circ}$. Immediate roof is represented by clay shales being slightly metamorphosed rocks, with the thickness up to $1.3 \mathrm{~m}$, and belonging to rather unstable ones - B1-B2 (Ukrainian classification). The main roof is represented by argillites of general thickness up to $5 \mathrm{~m}$ belonging to rather unstable rocks prone to fissuring - A1 (Ukrainian classification).

The caving step of the immediate roof is: initial $\left(l_{b 0}\right)-$ $0.8 \mathrm{~m}$; following $\left(l_{b i}\right)-0.5 \mathrm{~m}$.

The caving step of the main roof is: initial $\left(l_{k 0}\right)-12-15 \mathrm{~m}$; following $\left(l_{k i}\right)-7-9 \mathrm{~m}$.

Floor rocks are represented by unstable rocks - P1 (Ukrainian classification). They are prone to swelling and heaving. Mine working depth is $120-180 \mathrm{~m}$. Longwall operations are mechanized by means of powered complex $1 \mathrm{KD}-80$ with powered support D 80 . Coal shearer KA - 200 is a stopping machine. The scraper conveyor SP 251.14 transports loosened coal along the longwall. Lower limit of the reaction of valve blocks of hydraulic stands is adjusted for less than 320 Atm pressure to provide efficient rock pressure control in the longwall. Pressure range of high-pressure pump station is adjusted as follows: upper - not less than $260 \mathrm{Atm}$, lower - not less than $220 \mathrm{Atm}$.

From the practical viewpoint, three-dimensional visualization of each lithological difference of rocks is performed: along the stop (axis $X$ ), the extraction pillar (axis $Y$ ), and deep into the mass (axis $Z$ ). The following stage involves determination of basic characteristic zones of stress-strain state development. The coal extraction process is accompanied by changes in rock mass; these changes are quite easy to represent by means of simulation models. They are an efficient mechanism to make decisions as for mining operations and rock pressure control. Fig. 1 demonstrates a fragment of a mine 

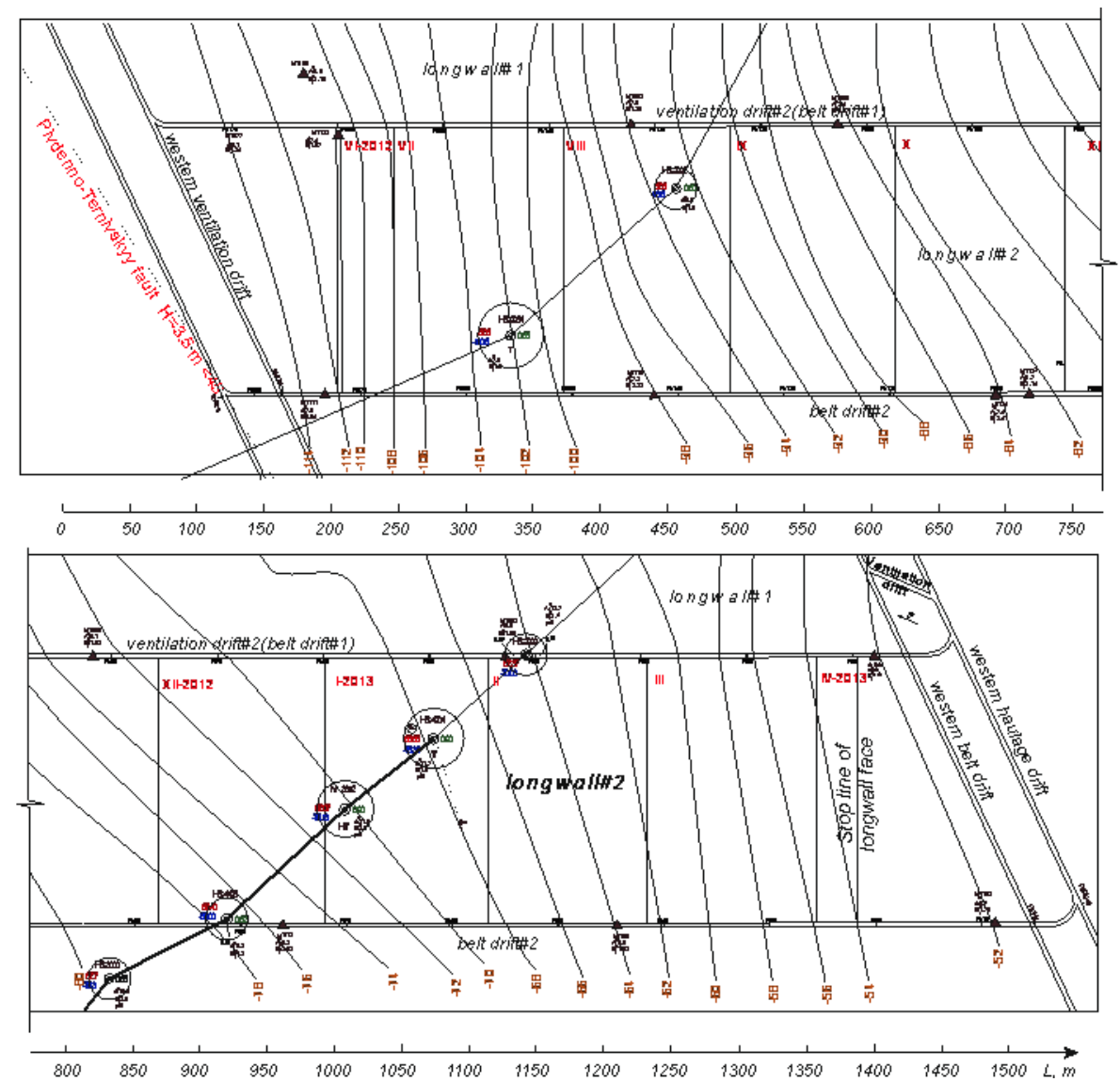

Fig. 1. A fragment of the mine plan

plan for this longwall. Using the principles developed [11], it was determined that while calculating the load on powered support units, mass of hanging rocks of general thickness being 4.1-6.2 m. is taken; that meets the standards for determining the required power parameters of a powered support. Contacts of lithological difference and determination of the areas of certain layers were represented with the help of similar mathematical mechanisms as in case of previous longwalls.

As a result of approximation, the following mathematical dependences were obtained to represent the lines of lithological difference of boundary (ventilation) entry:

1. $y_{1}=-0.25413+0.05084 x-1.1 E-0.4 x^{2}+2,72 E-0.7 x^{3}-$ $-4.05 E-10 x^{4}-2.91 E-13 x^{5}-7.72 E-17 x^{6}$, certainty is $R^{2}=$ $=0.9781$;

2. $y_{2}=0.049772+0.0512 x-1.05 E-04 x^{2}+248 E-0.7 x^{3}-$ $-3.7 E-10 x^{4}+2.7 E-13 x^{5}-7.26 E-17 x^{6}$, certainty is $R^{2}=$ $=0.9942$;

3. $y_{3}=2.90005+0.04797 x-1.01 E-0.4 x^{2}+2.53 E-0.7 x^{3}-$ $-3.84 E-10 x^{4}+2.85 E-13 x^{5}-7.78 E-17 x^{6}$, certainty is $R^{2}=$ $=0.9861$;

4. $y_{4}=3.3992-0.01554 x+1.69 E-0.4 x^{2}-3.8 E-0.7 x^{3}+$ $+2.31 E-10 x^{4}+3.97 E-14 x^{5}-4.88 E-17 x^{6}$, certainty is $R^{2}=$ $=0.9831$;

5. $y_{5}=8.25671+0.02436 x+9.94 E-0.5 x^{2}-2.01 E-0.7 x^{3}+$ $+1.7 E-11 x^{4}+1.6 E-13 x^{5}-7.46 E-17 x^{6}$, certainty is $R^{2}=$ $=0.9913$;

6. $y_{6}=22.15273+0.0262 x+2.1 E-0.5 x^{2}+8.9 E-0.8 x^{3}+$ $+4.01 E-10 x^{4}+4.25 E-13 x^{5}-1.36 E-16 x^{6}$, certainty is $R^{2}=$ $=0.9854$.

To represent lines of lithological difference for belt entry:

1. $y_{1}=-0.10091+0.04459 x-6.35 E-0.5 x^{2}+1.85 E-$ $-0.7 x^{3}-3.55 E-10 x^{4}+2.99 E-13 x^{5}-8.72 E-17 x^{6}$, certainty is $R^{2}=0.9794$;

2. $y_{2}=0.66546+0.04485 x-5.84 E-0.5 x^{2}+1.5 E-0.7 x^{3}-$ $-2.84 E-10 x^{4}+2.43 E-13 x^{5}-7.19 E-17 x^{6}$, certainty is $R^{2}=$ $=0.9885$;
3. $y_{3}=1.02587+0.0713 x-2.55 E-0.4 x^{2}+6.83 E-0.7 x^{3}-$ $-9.46 E-10 x^{4}+6.27 E-13 x^{5}-1.56 E-16 \mathrm{x}^{6}$, certainty is $R^{2}=$ $=0.9932$;

4. $y_{4}=1.6663-0.03289 x+6.42 E-0.5 x^{2}-1.64 E-0.7 x^{3}+$ $+7.94 E-11 x^{4}-4.22 E-14 x^{5}-2.83 E-17 x^{6}$, certainty is $R^{2}=$ $=0.9799$;

5. $y_{5}=7.43181-0.04191 x-5.53 E-0.6 x^{2}+1.44 E-0.8 x^{3}-$ $-1.49 E-10 x^{4}+1.91 E-13 x^{5}-6.66 E-17 x^{6}$, certainty is $R^{2}=$ $=0.9911$;

6. $y_{6}=21.8129-0.01932 x-2.29 E-0.5 x^{2}+3.59 E-0.7 x^{3}-$ $-8.87 E-10 x^{4}+7.72 E-13 x^{5}-2.28 E-16 x^{6}$, certainty is $R^{2}=$ $=0.9727$.

Results of the determination of lithological difference areas in terms of cross-sections of site entries as well as the coefficient of area variation along the stope and extraction pillar are presented in Table 1.

Numerical values of the coefficient of lithological structure show that their values are within the range of $0.5-0.8$. It demonstrates the fact that the use of powered complex $1 \mathrm{KD}-$

Table 1

Results of variation of the area of rock lithological difference in terms of site entries of the presented longwall

\begin{tabular}{|c|c|c|c|}
\hline Number & $\begin{array}{c}\text { Change in lithological } \\
\text { difference areas in } \\
\text { terms of ventilation } \\
\text { entry, } \mathrm{m}^{2}\end{array}$ & $\begin{array}{c}\text { Change in lithological } \\
\text { difference areas in } \\
\text { terms of belt entry, } \mathrm{m}^{2}\end{array}$ & $\begin{array}{c}\text { Coefficient } \\
\text { of area } \\
\text { variation, } \xi\end{array}$ \\
\hline 1 & 1180.0 & 990.0 & 1.19 \\
\hline 2 & 2210.0 & 1620.0 & 1.36 \\
\hline 3 & 4210.0 & 3140.0 & 1.34 \\
\hline 4 & 6520.0 & 7440.0 & 0.88 \\
\hline 5 & 18420.0 & 16410.0 & 1.12 \\
\hline
\end{tabular}


80 is in complete compliance with mining and geological conditions of the extraction pillar of longwall 172 in Samarska mine, DTEK company.

Similar studies were carried out for other extraction pillars (mentioned at the beginning of this chapter) of Lvivvuhillia SE and DTEK company with the potential to use innovative mining equipment. The obtained results are characterized by high convergence of analytical calculations and full-scale experiments. That makes it possible to draw conclusion on the fact that practical use of advanced equipment by domestic manufacturers (KD - 80, KD - 90, KD - 99, KM - 137, their modifications etc.) as well as by leading foreign producers of mining facilities applied in Ukrainian mines (Bycyrus, BM, Ostoj, Famur, Glinnik and others) with bearing capacity of powered support units being more than 30-40 (in some cases $50) \mathrm{tf} / \mathrm{m}^{2}$ removes all the support factor restrictions in the context of the considered mining regions. Zones of increased rock pressure of technogenic nature, geological disturbances, and seams dangerous in dynamic and geodynamic phenomena are the exceptions. In addition, there are individual cases of powered complexes with plough installations acting as an extracting machine with advance rates more than $10-15 \mathrm{~m} /$ day.

However, facilities with supports M87, M87, M101, M103 and their modifications are the basis of the powered complexes fleet used in Ukrainian mines; that is why the thesis research was aimed at the use of those mechanization means.

Use of innovative mining equipment makes it possible to increase coal extraction volumes up to $1000 \mathrm{t} /$ day. In some cases, the index reaches 3000-5000 t/day. Nevertheless, a considerable amount of coal is left in abandoned and noncommercial reserves being impossible to extract by means of modern means of mechanical breaking. These are the conditions for which drastic technology of underground gasification is proposed.

One of the disadvantages of underground gasification is its low productivity. It is possible to increase only by extensive means - at the expense of increasing the number of gas generators operating simultaneously. The paper proposes to implement compensation of that negative side of WUCG by means of complex and mechanized coal extraction.

Synthesis of technologies to mine thin and very thin coal seams within one mine makes it possible to solve a topical problem of full coal reserves development [16]. That is the objective to bear in mind for comprehensive substantiation of technological parameters of underground coal gasification with a focus on rational composition of end power gas.

Basing upon the practice of mining equipment operation as well as upon the analysis of the available developments concerning the efficiency of powered complexes operation in stopes in the context of flat seams and slightly metamorphosed rocks [16], it is possible to single out the following zones as for the expediency to use facilities in terms of the support factor:
- $<0.6$ - economically inexpedient zone due to underloading of powered complexes;

- 0.6-0.8 - mining and technical provision meets mining and geological conditions;

$-0.8-1.1-$ it is possible to use powered complexes, if there are additional support elements;

$->1.1$ - it is inadmissible to use mining equipment without extra measures in terms of the support factor.

Zones of values of lithological structure coefficient being less than 0.6 and more than 1.1 indicate the necessity to replace mining equipment. Taking into consideration the fact that the research carried out in the framework of the paper considers coal reserves occurring in slightly metamorphosed rocks and use of increased temperatures in the process of well underground gasification results in certain changes in metamorphic properties of the surrounding rocks, these are the boundaries for which it is proposed to develop improved techniques to extract coal with the help of WUCC.

Economic aspects. For selecting methods of economic evaluation it was indicated that the equipment to mine coal of the extraction pillar as well as mining technologies is a highbudget investment project. Thus, capital investment should involve comprehensive evaluation of the initiative expediency. Actually, almost all the available approaches and mathematical mechanisms to evaluate investment attractiveness of mining industry and the related industries are based upon the methods developed by the United Nations Industrial Development Organization (UNIDO) as early as in the 1970s. The methods make it possible to collect necessary data for cash flow prognosis and evaluate the project with the use of quantitative indices [17]. Moreover, the methods help perform both preliminary and complete feasibility evaluation of financial initiatives and determine risks concerning their implementation [18].

Criteria to evaluate business projects relying upon the standards, recommended by the UNIDO, are under constant study and analysis of scientists since despite the methods are of universal nature, they have controversies as for the calculation of certain parameters connected with evaluation of cash flows. A process of potential cash value reduction to their current value is discounting. It helps to determine the amount of actual investment to earn profits in future.

Practically, the issue is determination of the current value of the required capital investment $[8,19,20]$. It is expedient to make the calculations using a discount coefficient.

Our investment object is located at the territory of Western Donbas. In terms of the project, it had to be implemented during twelve months; actually, extraction of the longwall took less time, i.e. 11 months. It is expedient to show the results, obtained during each stage of the project planning and implementing (Tables 2 and 3).

The data explain clearly that in case two actual results are even better than that of target ones; moreover, profit is higher

Target values of profit and cost for the examined longwall

\begin{tabular}{|c|c|c|c|c|c|c|c|c|c|c|c|c|}
\hline \multirow{2}{*}{ Index } & \multicolumn{12}{|c|}{ Implementation period of the project, number of a month } \\
\hline & 1 & 2 & 3 & 4 & 5 & 6 & 7 & 8 & 9 & 10 & 11 & 12 \\
\hline Profit*, UAH, million & 20.8 & 49.7 & 49.7 & 49.7 & 49.7 & 49.7 & 49.7 & 49.7 & 49.7 & 49.7 & 49.7 & 27.6 \\
\hline Cost $^{* *}$, UAH, million & 111.1 & 12.6 & 12.6 & 12.6 & 12.6 & 12.6 & 12.6 & 12.6 & 12.6 & 12.6 & 12.6 & 57.3 \\
\hline Net profit/loss ${ }^{* * *}$, UAH, million & -90.3 & 37.1 & 37.1 & 37.1 & 37.1 & 37.1 & 37.1 & 37.1 & 37.1 & 37.1 & 37.1 & -29.7 \\
\hline $\begin{array}{l}\text { Net resource profit/loss (with accruing } \\
\text { result), UAH, million }\end{array}$ & -90.3 & -53.2 & -16.1 & 21.0 & 58.1 & 95.2 & 132.3 & 169.4 & 206.5 & 243.6 & 280.7 & 251 \\
\hline
\end{tabular}

* Total profit is UAH 544.500 million;

** UAH 294.400 million - budget cost; UAH 168.400 million - cost of key assets (i.e. powered system); UAH 126.600 million - operating cost; UAH 57.300 million - cost to take the powered system out of service;

${ }^{* * *}$ UAH 251.100 million - target profit 
for a period being less than a month. To obtain reliable information concerning actual value of the required capital investment and profits, it is necessary to refer to NPV resulting from the project implementation. The rate of return is still $15 \%$. Tables 4 and 5, and Fig. 2 demonstrate the calculation results concerning discounting coefficient and NPV.

Research conclusions and recommendations. The obtained research results help conclude the following:

- actual index of the total discounted profit turned out to be by $20 \%$ more than that of the target one. In this context, NPV is positive in terms of target values and actual values. Thus, the investment decision should be positive categorically. The obtained indices are close-valued meaning that preparatory period for the project implementation is well-staged;
- profitability index variation resembles NPV variation since calculation of the criterion involves total NPV index relative to the initial capital investment (i.e. cost of the powered system). The actual coefficient even turned out to be more than the target coefficient by $20 \%$. The fact that profitability index is more than 0 is the final criterion to make investment decision;

- the project payback period is similar in terms of target values and actual values; it is 3 months.

Taking into consideration the data of economic evaluation of investment project 3, one may conclude that the proposed technical and technological solutions as for the extraction pillar mining are the most attractive from the viewpoint of the listed investment objects. However, the greatest advantage of

Table 3

Actual profit/cost indices for the examined longwall

\begin{tabular}{|l|c|c|c|c|c|c|c|c|c|c|c|}
\hline \multicolumn{1}{|c|}{ Number of a month } & 1 & 2 & 3 & 4 & 5 & 6 & 7 & 8 & 9 & 10 & 11 \\
\hline Profit*, UAH, million & 1.7 & 52.7 & 53.6 & 52.9 & 53,6 & 52.9 & 53.5 & 53.6 & 52.9 & 53.7 & 45.9 \\
\hline Cost**, UAH, million $^{*}$ (11.1 & 12.6 & 12.6 & 12.6 & 12.6 & 12.6 & 12,6 & 12.6 & 12.6 & 12.6 & 57.3 \\
\hline Net profit/loss**, UAH, million & -91.4 & 40.1 & 41.0 & 40.3 & 41.0 & 40.3 & 40.9 & 41.0 & 40.3 & 41.1 & -11.4 \\
\hline $\begin{array}{l}\text { Net resource profit/loss (with accruing result), UAH, } \\
\text { million }\end{array}$ & -91.4 & -51.3 & -10.3 & 30.0 & 71.0 & 111.3 & 152.2 & 193.2 & 233.5 & 274.6 & 263.2 \\
\hline
\end{tabular}

* UAH 545.000 million - total profit;

${ }^{* *}$ UAH 281.100 million - total cost resulting from the project implementation by the mine; UAH 168.400 million - cost of key assets (i.e. powered system); UAH 112.700 million - operating cost inclusive of the putting into operation of the powered system and its taking out of service;

*** UAH 263.900 million - target profit

Table 4

Net present value of the investment project (target values) for the examined longwall

\begin{tabular}{|l|c|c|c|c|c|c|c|c|c|c|c|c|}
\hline \multicolumn{1}{|c|}{ Number of a month } & 1 & 2 & 3 & 4 & 5 & 6 & 7 & 8 & 9 & 10 & 11 & 12 \\
\hline $\begin{array}{l}\text { Discounting coefficient (15\% } \\
\text { rate of return 15\%) }\end{array}$ & 1.0 & 0.988 & 0.975 & 0.963 & 0.951 & 0.939 & 0.928 & 0.917 & 0.905 & 0.894 & 0.883 & 0.872 \\
\hline $\begin{array}{l}\text { Discounted profit/loss, UAH, } \\
\text { million }\end{array}$ & -90.3 & 36.64 & 36.19 & 35.74 & 35.30 & 34.86 & 34.43 & 34.01 & 33.59 & 33.18 & 32.77 & -25.90 \\
\hline $\begin{array}{l}\text { Resource discounted profit/loss } \\
\text { (with accrued result), UAH, } \\
\text { million }\end{array}$ & -90.3 & -53.66 & -17.47 & 18.27 & 53.57 & 88.44 & 122.88 & 156.88 & 190.48 & 223.65 & 256.41 & 230.51 \\
\hline
\end{tabular}

Table 5

Net present value of the investment project (actual values) for the examined longwall

\begin{tabular}{|l|c|c|c|c|c|c|c|c|c|c|c|}
\hline \multicolumn{1}{|c|}{ Number of a month } & 1 & 2 & 3 & 4 & 5 & 6 & 7 & 8 & 9 & 10 & 11 \\
\hline $\begin{array}{l}\text { Discounting coefficient (15\% rate of return } \\
15 \% \text { ) }\end{array}$ & 1 & 0.988 & 0.975 & 0.963 & 0.952 & 0.94 & 0.928 & 0.917 & 0.905 & 0.894 & 0.883 \\
\hline Discounted profit/loss, UAH, million & -91.4 & 39.60 & 39.99 & 38.82 & 43.08 & 42.88 & 44.06 & 44.72 & 44.51 & 45.96 & -12.91 \\
\hline $\begin{array}{l}\text { Resource discounted profit/loss (with accrued } \\
\text { result), UAH, million }\end{array}$ & -91.4 & -51.79 & -11.80 & 27.025 & 70.11 & 112.99 & 157.06 & 201.79 & 246.29 & 292.26 & 279.35 \\
\hline
\end{tabular}

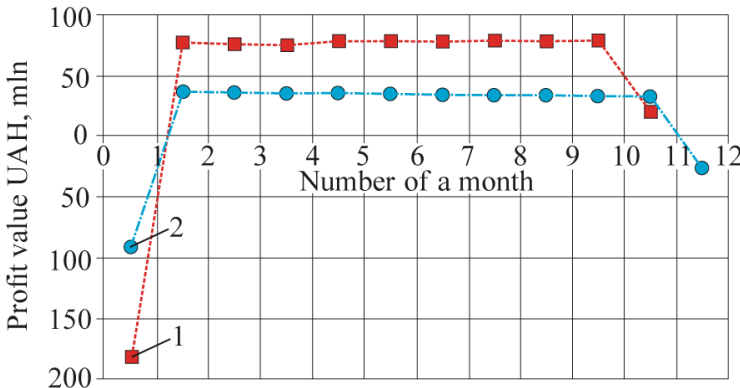

Fig. 2. Dynamics of changes in the net discounted profit of the value (target values and actual values):

1 - Discounted profit (i.e. NPV actual) UAH, million; 2 - Discounted profit (i.e. NPV target) UAH, million the three object investment is the following: implementation period is even shorter than the target period and profit of investors is by $20 \%$ greater compared with the planned profit.

Relying upon the research and supposing that real economic effect may achieve $10-20 \%$ of target one, it is possible to say confidently that monthly economic implementation effect is UAH 1.2-1.3 million per this working area.

Acknowledgements. This work was supported by the Ministry of Education and Science of Ukraine, grants No. 0119 U000248 and No. 0117 U001127.

\section{References.}

1. Lozynskyi, V., Dychkovskyi, R., Saik, P., \& Falshtynskyi, V. (2018). Coal Seam Gasification in Faulting Zones (Heat and Mass Balance Study). Solid State Phenomena, (277), 66-79. DOI: 10.4028/www.scientific.net/SSP.277.66. 
2. Petlovanyi, M.V. (2018). Modern experience of low-coal seams underground mining in Ukraine. International Journal of Mining Science and Technology, 28(6), 917-923. DOI: 10.1016/j.ijmst.2018.05.014.

3. Malanchuk, Ye., Korniienko, V., Moshynskyi, V., Soroka, V., Khrystyuk, A., \& Malanchuk, Z. (2019). Regularities of hydromechanical amber extraction from sandy deposits. Mining of Mineral Deposits, 13(1), 49-57. DOI: 10.33271/mining13.01.049.

4. Bondarenko, V., Tabachenko, M., \& Wachowicz, J. (2010). Possibility of production complex of sufficient gasses in Ukraine. New Techniques and Technologies in Mining, 113-119. DOI: $10.1201 /$ b11329-1.

5. Cempa, M., \& Smoliński, A. (2017). Reactivity of chars gasified in a fixed bed reactor with the potential utilization of excess process heat. Journal of Sustainable Mining, 16(4), 156161. DOI: $10.1016 /$ j.jsm.2017.12.001.

6. Gorova, A., Pavlychenko, A., Borysovs'ka, O., \& Krups'ka, L. (2013). The development of methodology for assessment of environmental risk degree in mining regions. Annual Scientific-Technical Colletion - Mining of Mineral Deposit, 207209. DOI: 10.1201/b16354-38.

7. Khomenko, O., Kononenko, M., \& Myronova, I. (2013). Blasting works technology to decrease an emission of harmful matters into the mine atmosphere. Annual Scientific-Technical Colletion - Mining of Mineral Deposit, 231-235. DOI: 10.1201/ b16354-43.

8. Golovchenko, A. (2018). Automated Monitoring of Physical Processes of Formation of Burden Material Surface and Gas Flow in Blast Furnace, Solid State Phenomena, (277), 5465. DOI: 10.4028/www.scientific.net/SSP.277.54.

9. Sobolev, V. V., \& Usherenko, S. M. (2006). Shock-wave initiation of nuclear transmutation of chemical elements. Journal De Physique, IV, 977-982. DOI: 10.1051/jp4:2006134149.

10. Dychkovskyi, R., Vladyko, O., Maltsev, D., \& Cabana, E. (2018). Some aspects of the compatibility of mineral mining technologies. Rudarsko Geolosko Naftni Zbornik, 33(4), 73-82. DOI: 10.17794/rgn.2018.4.7.

11. Pivnyak, G. (2018). Mathematical and Geomechanical Model in Physical and Chemical Processes of Underground Coal Gasification, Solid State Phenomena, (277), 1-16. DOI: 10.4028/www.scientific.net/SSP.277.1.

12. Malanchuk, Z., \& Malanchyk, Ye. (2018). Substantiation into mass and heat balance for underground coal gasification in faulting zones. Inzynieria Mineralna, 19(2), 289-300. DOI: 10.29227/IM-2018-02-36.

13. Dychkovskyi, R. O. (2015). Forming the bilayer artificially shell of georeactor in underground coal gasification. Naukovyi Visnyk Natsionalnoho Hirnychoho Universytetu, 5, 37-42.

14. Dychkovskyi, R. O. (2015). Determination of the rock subsidence spacing in the well underground coal gasification. Naukovyi Visnyk Natsionalnoho Hirnychoho Universytetu, 6, 30-36.

15. Kuttykadamov, M.E., Rysbekov, K.B., Milev, I., Ystykul, K.A., \& Bektur, B. K. (2016). Geodetic monitoring methods of high-rise constructions deformations with modern technologies application. Journal of Theoretical and Applied Information Technology, 93(1), 24-31.

16. Sotskov, V., \& Saleev, I. (2013). Investigation of the rock massif stress strain state in conditions of the drainage drift overworking. Annual Scientific-Technical Colletion - Mining of Mineral Deposits, 197-201. DOI: 10.1201/b16354-36.

17. Jadhav, J. R., Mantha, S. S., \& Rane, S. B. (2014). Roadmap for Lean implementation in Indian automotive component manufacturing industry: comparative study of UNIDO Model and ISM Model. Journal of Industrial Engineering International, 11(2), 179-198. DOI: 10.1007/s40092-014-0074-6.

18. Ilyashov, M., Diedich, I., \& Nazimko, V. (2019). Prospective tendencies of coal mining risk management. Mining of Mineral Deposits, 13(1), 111-117. DOI: 10.33271/mining 13.01.111.
19. Dychkovskyi, R. O., Avdiushchenko, A.S., Falshtynskyi, V.S., \& Saik, P. B. (2013). On the issue of estimation of the coal mine extraction area economic efficiency. Naukovyi Visnyk Natsionalnoho Hirnychoho Universytetu, 4, 107-114. 20. Piwniak, G. G. (2007). Limits to economic viability of extraction of thin coal seams in Ukraine. Technical, Technological and Economic Aspects of Thin-Seams Coal Mining International Mining Forum 2007, 129-132. DOI: 10.1201/ noe $0415436700 . \operatorname{ch} 16$.

\section{Технологічні, літологічні та економічні аспекти геометризації даних при видобуванні вугілля}

\section{Р. О. Дичковський ${ }^{1}$, В. Г. Лозинський ${ }^{1}$, П. Б. Саӥк ${ }^{1}$, Ю. В. Дубєй, Е. Касерес Кабана ${ }^{2}$, Я. Т. Шаварський}

1 - Національний технічний університет „Дніпровська політехніка“, м. Дніпро, Україна, e-mail: dychkovskyi.r.o@ nmu.one

2 - Науково-дослідний інститут Центру відновлювальної енергетики та енергоефективності Університету Святого Августина, м. Арекіпа, Перу, e-mail: ecaceresca@unsa.edu.pe 3 - ТОВ „ЯРАД технології рециклінгу“, м. Смольніца, Польща, e-mail: shawslav@gmail.com

Мета. Створення сприятливої геомеханічної ситуації та установка економічних параметрів на гірничодобувній дільниці залежно від відповідного техніко-технологічного обгрунтування та режимів роботи механізованого кріплення на основі планування зон змінної напруженості.

Методика. Застосовані методи математичного моделювання для визначення навантажень на кріплення механізованих комплексів, виконані експериментальні дослідження напружено-деформованого стану масиву, на основі яких сформовані раціональні параметри ведення гірничих робіт і управління гірським тиском.

Результати. Із використанням розробленого методу геометризації даних було представлено літолого-геологічну будову масиву гірських порід по довжині оточуючих лаву двох підготовчих виробок. На цій основі встановлена зміна напружено-деформованого стану масиву гірських порід. Це дозволяє визначати навантаження на кріплення механізованих комплексів. Цей підхід формує математичні залежності, що дають можливість визначати зони підвищеного й пониженого гірського тиску. Як критерій перехідності встановлюється так званий коефіцієнт літологічної різниці. Цей параметр дає можливість не тільки оцінити геомеханічну ситуацію на добувних ділянках, але й сформувати зони переходу для відпрацювання запасів з використанням традиційних і радикальних технологій. Окремо була проведена економічна оцінка запропонованих техніко-технологічних рішень. Результати дослідження дозволять обгрунтувати ефективне відпрацювання запасів вугілля в конкретних геологічних умовах.

Наукова новизна. Встановлені залежності формування даних літологічної різниці порід і напруженості гірського масиву для створення умов відпрацювання ділянки вугільних запасів. Проведена економічна оцінка прийнятих рішень за допомогою відомої методики UNIDO.

Практична значимість. Отримані результати експериментальних досліджень із достатньою для практичного застосування точністю можуть бути використані для визначення параметрів підземної розробки й забезпечення можливості вилучення запасів вугілля на економічно доцільному рівні. Запропоновані технологічні рішення перевірялися у практичних умовах для розробки запасів вугілля на ділянці шахти компанії ДТЕК. 
Ключові слова: геометризація даних, літологічна будова, вугільні запаси, традиційні й радикальні технології, економічна оцінка

\section{Технологические, литологические и экономические аспекты геометризации данных при добыче угля}

Р. Е. Дычковский ${ }^{1}$, В. Г. Лозинский ${ }^{1}$, П. Б. Саик ${ }^{1}$, Ю. В. Дубей, Е. Касерес Кабана 2 , Я. Т. Шаварский

1 - Национальный технический университет „Днепровская политехника“, г. Днепр, Украина, e-mail: dychkovskyi.r.o@nmu.one

2 - Научно-исследовательский институт Центра возобновляемой энергетики и энергоэффективности Университета Святого Августина, г. Арекипа, Перу, e-mail: ecaceresca@unsa.edu.pe

3 - ООО „ЯРАД технологии рециклинга“, г. Смольница, Польша, e-mail: shawslav@gmail.com

Цель. Создание благоприятной геомеханической ситуации и установка экономических параметров на горнодобывающем участке в зависимости от соответствующего технико-технологического обоснования и режимов работы механизированного крепления на основе планирования зон переменных напряжений.

Методика. Применены методы математического моделирования для определения приходящихся нагрузок на крепь механизированных комплексов, выполнены экспериментальные исследования напряженно-деформированного состояния массива, на основе которых сформированы рациональные параметры ведения горных работ и управления горным давлением.

Результаты. С использованием разработанного метода геометризации данных было представлено литологогеологическое строение массива горных пород по длине окружающих лаву двух подготовительных выработок. На этой основе установлено изменение напряженно-деформированного состояния массива горных пород. Это позволяет определять нагрузку на крепь механизированных комплексов. Этот подход формируют математические зависимости, которые дают возможность определять зоны повышенного и пониженного горного давления. В качестве критерия переходности устанавливается так называемый коэффициент литологической разности. Этот параметр дает возможность не только оценить геомеханическую ситуацию на добычном участке, но и сформировать зоны перехода для разработки запасов с использованием традиционных и радикальных технологий. Отдельно была проведена экономическая оценка предлагаемых технико-технологических решений. Результаты исследования позволят обосновать эффективную отработку запасов угля в конкретных геологических условиях.

Научная новизна. Установлены зависимости формирования данных литологической разницы пород и напряженности горного массива для создания условий отработки участка угольных запасов. Проведена экономическая оценка принятых решений с помощью известной методики UNIDO.

Практическая значимость. Полученные результаты экспериментальных исследований с достаточной для практического применения точностью могут быть использованы для определения параметров подземной разработки и обеспечения возможности извлечения запасов угля на экономически целесообразном уровне. Предложенные технологические решения проверены в практических условиях для разработки запасов угля на участке шахты компании ДТЭК.

Ключевые слова: геометризация данных, литологическое строение, угольные запасы, традииионные и радикальные технологии, экономическая оценка

Рекомендовано до публікації докт. техн. наук I. А. Ковалевською. Дата надходження рукопису 15.12.18. 